\section{Asymmetric intergroup bullying: The enactment and maintenance of societal inequality at work}

2015, Vol. 68(7) 1099-1129

(C) The Author(s) 2015

(c) (1) (8)

Reprints and permissions: sagepub.co.uk/journalsPermissions.nav DOI: I0.II77/00|87267|455200 I hum.sagepub.com

(SAGE

\title{
Soydan Soylu
}

Middlesex University, UK

\section{Jennifer Sheehy-Skeffington'}

Harvard University, USA

\begin{abstract}
What does inequality mean for dysfunctional organizational behaviours, such as workplace bullying? This article argues that workplace bullying can be understood as a manifestation of intergroup dynamics originating beyond the organization. We introduce the construct of asymmetric intergroup bullying: the disproportionate mistreatment of members of low status groups, with the intended effect of enhancing the subordination of that group in society at large. Analysis of data from 38 interviews with public and private sector workers in Turkey depicts a pattern of asymmetric intergroup bullying, undertaken to achieve organizational and broader sociopolitical goals. Respondents reported bullying acts used to get rid of unwanted personnel, with the goal of avoiding severance pay, or of removing supporters of the former government from positions of political and economic influence. Bullying was also described as working towards the dominance of the sociocultural worldview of one political group over another. We discuss asymmetric intergroup bullying as one mechanism through which acute intergroup hierarchy in the broader society corrupts management practice and employee interactions, in turn exacerbating economic inequality along group lines.
\end{abstract}

\section{Keywords}

bullying, inequality, intergroup relations, management, qualitative, social dominance theory, Turkey, workplace

\section{Corresponding author:}

Soydan Soylu, Department of Leadership, Work, and Organisations, Middlesex University Business School, The Burroughs, London NW4 4BT, UK.

Email: s.soylu@mdx.ac.uk 
The case of workplace bullying can signal management practice at its most dysfunctional. A pervasive and harmful phenomenon, bullying is usually studied as a product of individual and institutional antecedents (Einarsen et al., 2011), and a contributor to negative intra-organizational outcomes such as decreased productivity and job satisfaction (Hoel et al., 2011). Departing from this literature, our premise is that some forms of bullying can only be understood by looking beyond the workplace, to the broader society in which an organization is embedded. Expanding the lens of management research in this manner (see also Côté, 2012; DiTomaso et al., 2007), this article presents qualitative evidence for the manifestation of sociopolitical inequality in the phenomenon of workplace bullying in Turkey.

Just as bullying has societal antecedents, so it may have societal consequences. Based on theories that posit bullying as a strategic phenomenon (Salin, 2003a) and organizations as sites of conflict over power and resources (Sidanius and Pratto, 1999; Weber, 1968), we further explore whether the patterns of bullying observed might herald changing trends in economic inequality relevant to, though not yet visible at, the level of wider society.

\section{Defining the problem}

Described as the 'silent epidemic', workplace bullying is slowly becoming a troublesome and ubiquitous reality of institutional life (McAvoy and Murtagh, 2003). Bullying is 'the systematic mistreatment of a subordinate, a colleague, or a superior, which if continued and long-lasting, may cause severe social, psychological and psychosomatic problems in the target' (Einarsen et al., 2011: 4). Examples of acts of bullying include persistent verbal criticism, knowingly assigning inappropriate tasks, planned social isolation, and denigration of personal habits or beliefs (Einarsen et al., 2011). It is thus as much an issue for organizational culture and cooperation as it is for management practice. Yet it is difficult to stamp out, as it involves hostile interactions and subtle forms of cruelty, rather than the explicit breaking of rules (Rayner et al., 2002; see also Cortina et al., 2001).

Research on the antecedents of workplace bullying has maintained an almost exclusive focus on the individual and organizational levels (Einarsen et al., 2011). For example, Zapf and Einarsen (2011) state that perpetrators of bullying might suffer from lack of emotional control or social competence, and use bullying as a way to enhance their self-esteem. Similarly, the targets of bullying are portrayed as chosen owing to their personality or behaviours (Glaso et al., 2007). Few scholars have outlined the way in which bullying is used strategically to achieve goals that go beyond the intrapsychic or the interpersonal, to the political (Salin, 2003a). One exception is the work of Denise Salin, which outlines how perpetrators often use bullying to advance the status of themselves or their coalition at the cost of other individuals and groups. Salin (2003a) argues that such perpetrators are motivated to sabotage the job performance of co-workers in order to expel those who might get in the way of their own advancement.

Though this research (see also Ferris et al., 2007; Liefooghe and Davey, 2001) does acknowledge the political and instrumental nature of bullying, it nevertheless confines it to the interpersonal context, not elaborating on the role of goals that originate at the 
organizational level, let alone beyond the organization itself. In this article, we put characteristics of the wider society in which an organization is located at the centre of our analysis.

\section{Inequality as a driver of workplace bullying}

We propose that in times of societal polarization and inequality, contemporary manifestations of bullying in the workplace are in part a product of conflict playing out at the national level. Specifically, as inequality in all societies has an intergroup flavour (Sidanius and Pratto, 1999), there may be cases in which the salient social identities employees bring into the workplace from wider society might so colour their interactions as to produce patterns of behaviour classifiable as workplace bullying. This includes systematic incivility, which occurs along intergroup lines (Cortina et al., 2001), and also full-blown ridicule, mistreatment and social isolation, engaged in merely because of the social group identity of the actors and victims involved. This is consistent with the most influential multi-level theoretical frameworks in sociology and social psychology, which present the struggle between social coalitions, often organized in a hierarchical manner, as the defining feature of social life (Sidanius and Pratto, 1999; Tajfel and Turner, 1979; Weber, 1968).

Social dominance theory (Sidanius and Pratto, 1999) is one particular account of the origins and consequences of inequality between social groups that centres on mutually reinforcing processes at the individual, ideological and institutional levels. At the institutional level, the persistence of workplace discrimination along the lines of race, ethnicity and class is framed as part of a set of social dominance processes operating to keep power and resources in the hands of high status social groups, such as the White and wealthy in the USA (Sidanius and Pratto, 1999). Thus, it is not only that certain institutions function to subjugate some social groups, such as the police in the case of African Americans, but that diverse institutions can act as a site of group-based oppression, as a result of an intergroup asymmetry originating in the surrounding society and manifest in an imbalance of numbers or seniority in the organization (Sidanius and Pratto, 1999).

Similarly, conflict theories of ascriptive inequality identify corporations and public sector organizations as sites of struggle for access to power and resources by competing social groups (Sorensen, 2000; Tilly, 1998; Weber, 1968). Weber first described social closure as occurring when 'one group of competitors takes some externally identifiable characteristic of another group of (actual or potential) competitors - race, language, religion, local or social origin, descent, residence and so forth - as a pretext for attempting their exclusion' (Weber, 1968: 341-342). Nancy DiTomaso and colleagues bring this forward to the workplace diversity literature, outlining how the collective action of various social groups towards hoarding opportunities or economic advantages is likely to be evident at the intra-organizational level (DiTomaso et al., 2007: 478). These researchers point to the findings of Barbara Reskin (e.g. Reskin and Ross, 1992) as an example of how the interests of one social group are advanced at the expense of another through norm-setting, interpersonal interaction and the shaping of rules at work.

There are thus grounds to expect societal inequality to colour management practice and inter-employee relations in profound ways. Specifically, we propose that inequality 
and conflict between social groups at the societal level will produce what we call asymmetric intergroup bullying: bullying that is targeted disproportionately (i.e. asymmetrically) towards members of a low status social group, for the purpose of enhancing that group's subordination in society at large. When it takes place within organizations, this phenomenon may look a lot like workplace discrimination - institutionally enabled bias in the allocation of desirable opportunities and rewards towards particular social groups and not others (Dipboye and Colella, 2004). Indeed, when it takes the form of targeting low status group members, workplace bullying might be understood as one particular means through which discrimination is achieved, to the extent that resources and influence are denied to those who are ostracized or ridiculed (Lewis et al., 2011).

Yet this elucidation also highlights how asymmetric intergroup bullying does not conceptually collapse into discrimination. First, whereas discrimination operates through directly (if subtly) denying opportunities by virtue of social identity, asymmetric intergroup bullying operates indirectly, through causing psychological harm, which in turn elicits specific behaviours that are desirable to the perpetrators (Salin, 2003a). Second, whereas discrimination is usually enacted vertically from above, asymmetric intergroup bullying occurs on both vertical and horizontal planes, resting on a power imbalance that might originate from wider society rather than the organizational hierarchy itself. Finally, the reliance of intergroup bullying on interpersonal interactions and daily incivility makes it harder to police than discrimination. Unlike in cases in which bias can be demonstrated through asymmetric resource allocation within the organization, there is little that employment law can do to address the outcome of interpersonal nastiness, such as complaints from racial and ethnic minorities who feel underappreciated and excluded in the workplace as a result of their ethnicity (Barak et al., 1998; Ely and Thomas, 2001). Indeed, the grounding of asymmetric intergroup bullying in a set of wider societal inequalities and prejudices, and the concomitant normalization of intergroup maltreatment, may make it even harder to detect than other forms of workplace bullying.

\section{Inequality as a consequence of workplace bullying}

It is an easier empirical task to capture the workings of societal inequality as they colour workplace interactions than to demonstrate how such interactions might in turn affect societal inequality. Yet it is worth speculating how the pattern of dysfunctional management and organizational practice that we investigate in this article might affect the employees involved in a manner that impinges on intergroup outcomes at the national level. Of particular interest are the consequences of workplace bullying for the distribution of economic resources between competing social groups.

Research on the costs of workplace bullying has highlighted the severity of harm that bullying can cause, yielding damaging mental and physical symptoms in its victims, and signs of a marked decrease in quality of life. Bullying researchers have also observed impairments in self-esteem and social competence in those affected (Field, 1996; O’Moore et al., 1998), alongside reduced job performance and increased absenteeism. The literature draws out the consequences for the organization as a whole of such individual-level declines in motivation and performance, in the form of poor organizational 
productivity (Giga et al., 2008; McCarthy and Mayhew, 2004) and increased turnover (Lutgen-Sandvik, 2006).

If workplace bullying takes on an asymmetric intergroup dynamic, then its negative economic consequences will be disproportionally felt by members of some social groups and not others, with consequences not only for the individual and organization, but society at large. Indeed, the bullying literature provides clues as to how the targeting of bullying towards members of a group that is a minority in an organization, or has relatively little power in society at large, may enhance that group's subordination. Bullying victims who experience declines in work motivation, job performance, reputation and social competence receive poor work appraisals, and are thus impeded in their efforts to rise up to positions of influence and greater remuneration within the organization (Lee, 2000). Even more troubling, bullying victims are more likely than others to resign from the job or to retire early as a result of their bullying experience (Lutgen-Sandvik, 2006; Rayner, 1997), leaving them subject to the severe economic and personal costs of unemployment (Sen, 1997). It is not difficult to see how asymmetric intergroup bullying, if sustained and widespread, decreases the representation of low status group members in high-paid positions at the top of society, while increasing their representation among the ranks of the unemployed and underpaid. Economic inequality along group lines is thus increased, realizing the theorized purpose of some forms of instrumentalized mistreatment: to achieve social closure (Weber, 1968) or intergroup dominance (Sidanius and Pratto, 1999) in power and resources.

Social structural theorists posit organizations as sites in which the production, reproduction and contestation of societal inequality operates (e.g. Reskin and Ross, 1992; Sidanius and Pratto, 1999; Tilly, 1998; Weber, 1968). We hope that bringing this sensitivity regarding intergroup inequality to the study of social interaction and management practices within organizations may shed much needed light on the mechanisms (as opposed to just the motives; see Reskin, 2003) through which inequality in a particular society takes shape. Its symptoms may be detectable either in an increase in populationlevel income inequality, or in the maintenance of the same economic gradient, but a change in the positioning of its occupants, as earnings are disproportionately allocated to one social group over another.

\section{Societal inequality between groups: The case of Turkey}

As the first investigation of the phenomenon of workplace bullying as a reflection of (and possible contributor to) inequality at the societal level, this article sets out to explore employee perspectives using a particularly illustrative case. We chose Turkey as the context for our study as it is currently experiencing an intense level of societal polarization along intergroup lines and has recently experienced a reversal in the relative political standing of its key social groups. When a group that previously had few resources or power suddenly gains political control, social forces should be triggered at the institutional, organizational and community levels in order to solidify the new hierarchy, fuelling an inversion of the distribution of money and resources across social groups (Sidanius and Pratto, 1999; Weber, 1968). This might set the broader societal politics of bullying in to particularly sharp relief. 
Since the country's founding, group-based social hierarchy in Turkey has been defined according to people's views about the appropriate role of religion in society and politics. Early political and social reforms led to the domination of those who claim to defend the state from religious influence, the so-called 'secularists', over those who advocate a closer relationship between religious and state affairs, the so-called 'Islamists' (Çarkoğlu and Toprak, 2007; Toprak et al., 2008). Though the topic of religion mobilizes each side, this conflict has a sociopolitical rather than a religious core; the term 'Islamist' referring to individuals who 'use Islam as a political ideology rather than a private religious belief system', but do not necessarily want a Sharia-based government (Arat, 1998: 123).

Twentieth century Turkey was dominated by a repressive form of secularism that allowed little space for religious expression (Arat, 1998; Başkan, 2010). The election in 2002 (and subsequent re-election in 2007 and 2011) of a parliamentary majority of the Islamist-leaning Justice and Development Party (AKP, hereafter) and with them a successful Islamist prime minister who was later elected president, marked a dramatic flip in this intergroup hierarchy. Analysts have observed a shift in the allocation of powerful positions in a range of public institutions towards supporters of the new regime (Hoşgör, 2011), leading to the trickle-down effect of installing a newly Islamist-leaning generation of managers in the public sector (Toprak et al., 2008). Meanwhile, in the private sector, it is claimed that the AKP has played a coordinating role in strengthening networks of Islamist-owned businesses, which, combined with preferential regulations and procurement decisions, prepared 'Islamic capital' to benefit the most from its neoliberal reforms (Hoşgör, 2011). Overall, the standing of Turkish Islamists has greatly increased at the cost of their secularist opponents in a number of domains (Toprak et al., 2008), going so far as to trigger public protest centred on claims of a reversal of the direction of repression (Seymour, 2013).

In using Turkey as a context for the study of asymmetric intergroup bullying, we were alert to two broad patterns derived from consideration of the organizational-societal interface. To the extent that one sociopolitical group is occupying a disproportionate number of powerful positions in Turkish organizations, we might predict asymmetric intergroup bullying to reflect attempts to strengthen one social, cultural and political worldview over another (Lewis et al., 2011; Toprak et al., 2008). Second, identity-related hostility can be driven by a desire to subordinate a low status group not only psychologically, but materially (Côté, 2011; DiTomaso et al., 2007). We thus paid further attention to bullying in Turkey as strategic in this sense, considering whether it may contribute to a matching of the country's shift in social and political power from secularists to Islamists with a shift in the economic realm.

Analyses of nationally representative survey data suggest that such a shift in economic position is already taking place. The make-up of the richest two-fifths of Turks has shifted from being predominantly secularist in 2007 to being equally secularist-Islamist in 2011, while those identifying as secularist now comprise more of the poorest twofifths of Turks than four years previously (KONDA, 2011). It is unlikely that this change reflects a shift in the allegiance of rich voters towards the party in power, as Islamist and secularist identities are very stable across the lifespan (and even generations; Arat, 1998), and very tied to their respective political parties (Keyman, 2010). In fact, these income data imply that though overall levels of inequality in Turkey have stabilized in recent 
years (Turkish Statistics Institute, 2012), the occupancy of the top and bottom positions in society seems to be switching from a previously dominant sociopolitical group to the newly dominant one. In the context of the preferential allocation of powerful roles to Islamists in organizations, asymmetric intergroup bullying may be one mechanism through which this shift occurs. We now turn to Turkish employees' accounts of the nature, antecedents and costs of bullying they have experienced or observed, at the same time staying alert to the wider societal context in which their organizations are situated.

\section{Method}

As we were exploring workplace behaviour at the intersection of previously unconnected analytical levels, we opted for an in-depth, qualitative research approach, which can provide a holistic account of a novel phenomenon and pick up on its unpredicted characteristics (Miles and Huberman, 1994). Between February 2011 and June 2013 (with the exception of three pilot interviews in July 2010) we conducted semi-structured interviews with 38 employees from 35 organizations. In order to reach employees from across the sociopolitical spectrum, we selected participants from the largest three cities in Turkey (Istanbul, Ankara, Izmir), which differ in the pattern of support for the main political parties. We employed non-probabilistic quota sampling in our study. First we placed emails inviting participation in a study of 'bullying in the Turkish workplace' to 'bumezbayanlar' and 'humanresourcesturkey' yahoo groups to recruit participants, with no stipulation that one need have directly experienced bullying (thus being open to victims, bystanders and perpetrators). From the list of prospective interviewees who reached us after the placement of emails, we selected 38 employees to represent as evenly as possible public and private sector organizations, gender and sociopolitical affiliation. As can be seen from Table 1, one-third of the participants held managerial positions. A majority (58\%) of the participants were female, and participant ages ranged from 25 to 65 years, with a mean age of 37 years. Interviewees worked in areas such as banking, municipality, health and education. Fourteen participants identified themselves as Islamist and 18 self-identified as secularist, the remaining six participants describing themselves as neither Islamist nor secularist.

The interviews ranged in duration from 35 minutes to 65 minutes, with an average duration of 55 minutes. They were conducted in Turkish by a Turkish national with no professed sociopolitical affiliation, and no remuneration was offered. The interview topic guide was informed by the research questions and the conceptual framework, and refined as the interviews progressed and key themes emerged. A funnel approach was employed, the interviews beginning with general questions about bullying, and progressing to more specific probes concerning its antecedents, nature and consequences. Themes covered in the topic guide, refined after three pilot interviews, included 'general experience at work', 'the meaning of workplace bullying', 'the role of group dynamics in experiencing bullying', and 'the impact of the political context on bullying at work'. The last two of these were added as pilot interviews pointed to their importance. Verbatim transcription and translation of the interviews were carried out by one of the authors. To ensure the integrity of the translations, we subjected three randomly selected interviews to back-translation: a person fluent in Turkish and English translated them from Turkish 


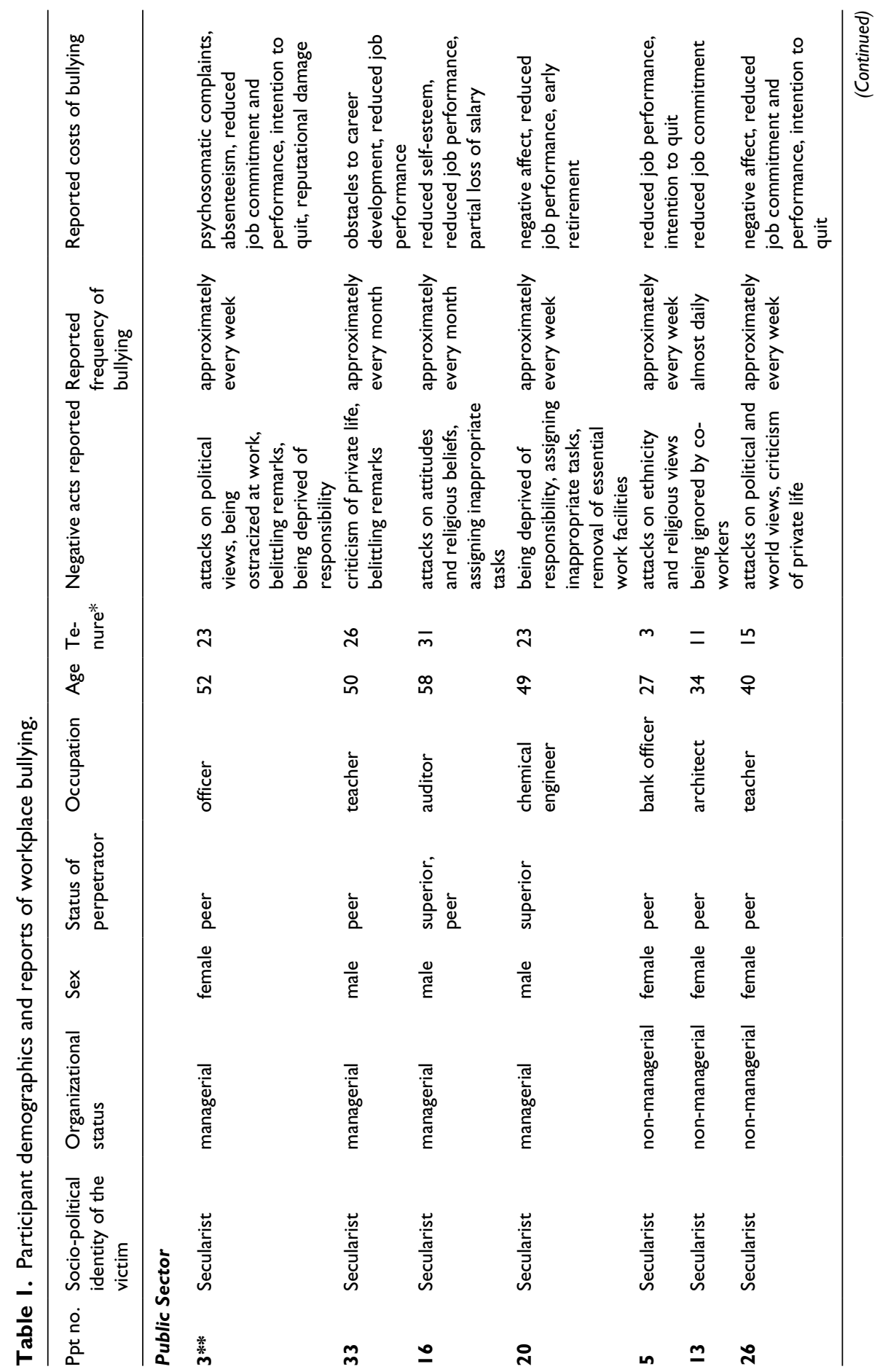




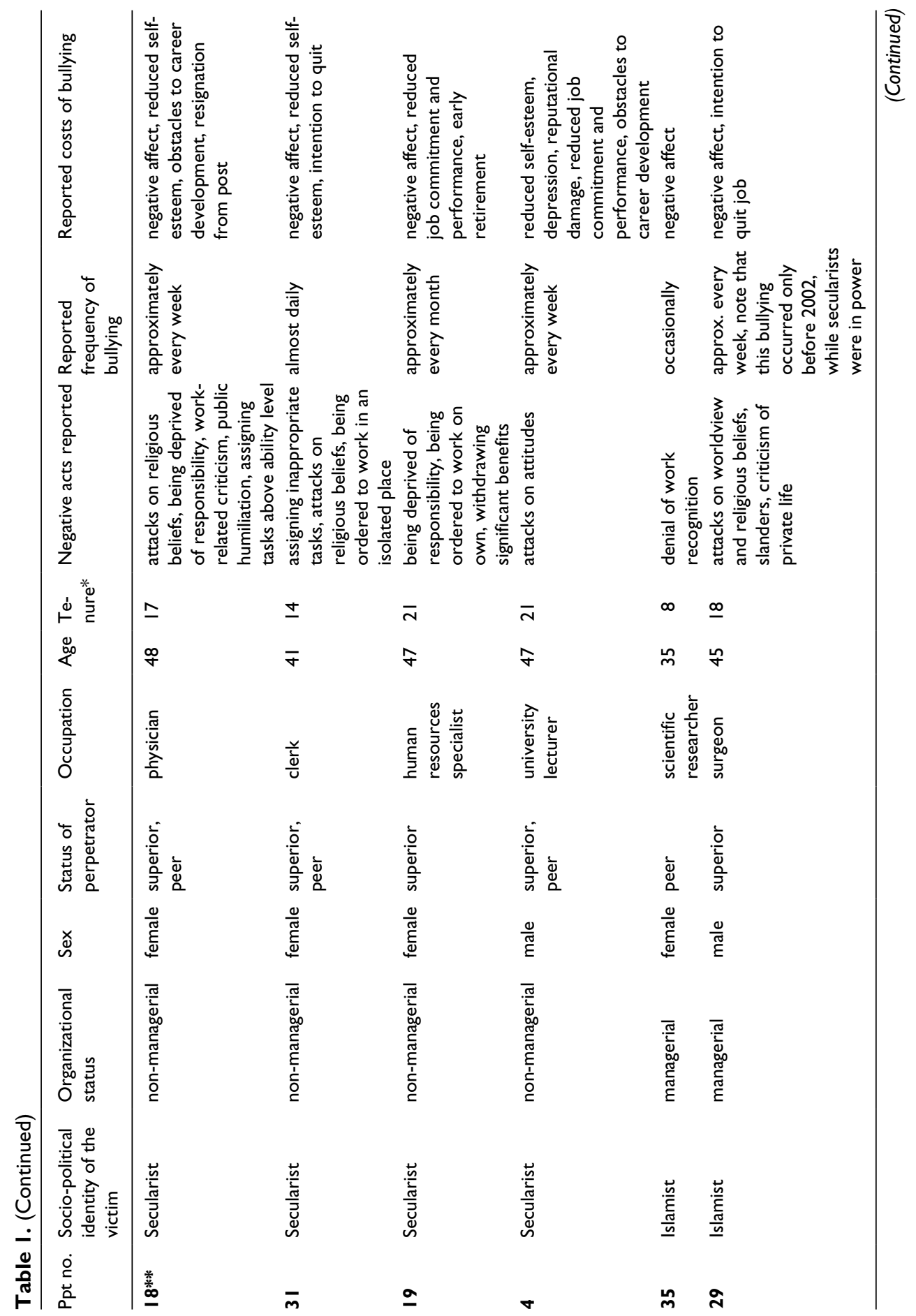




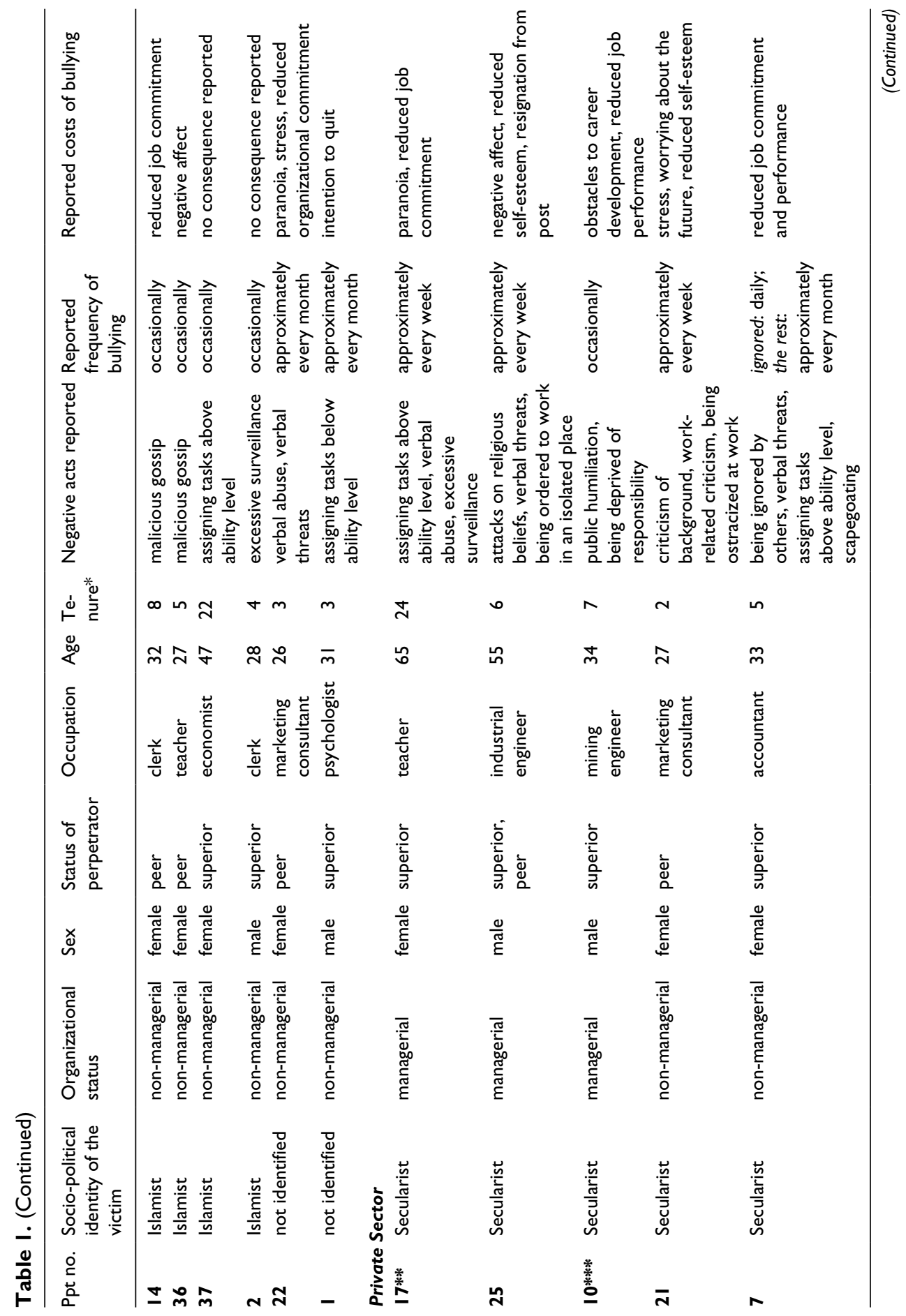




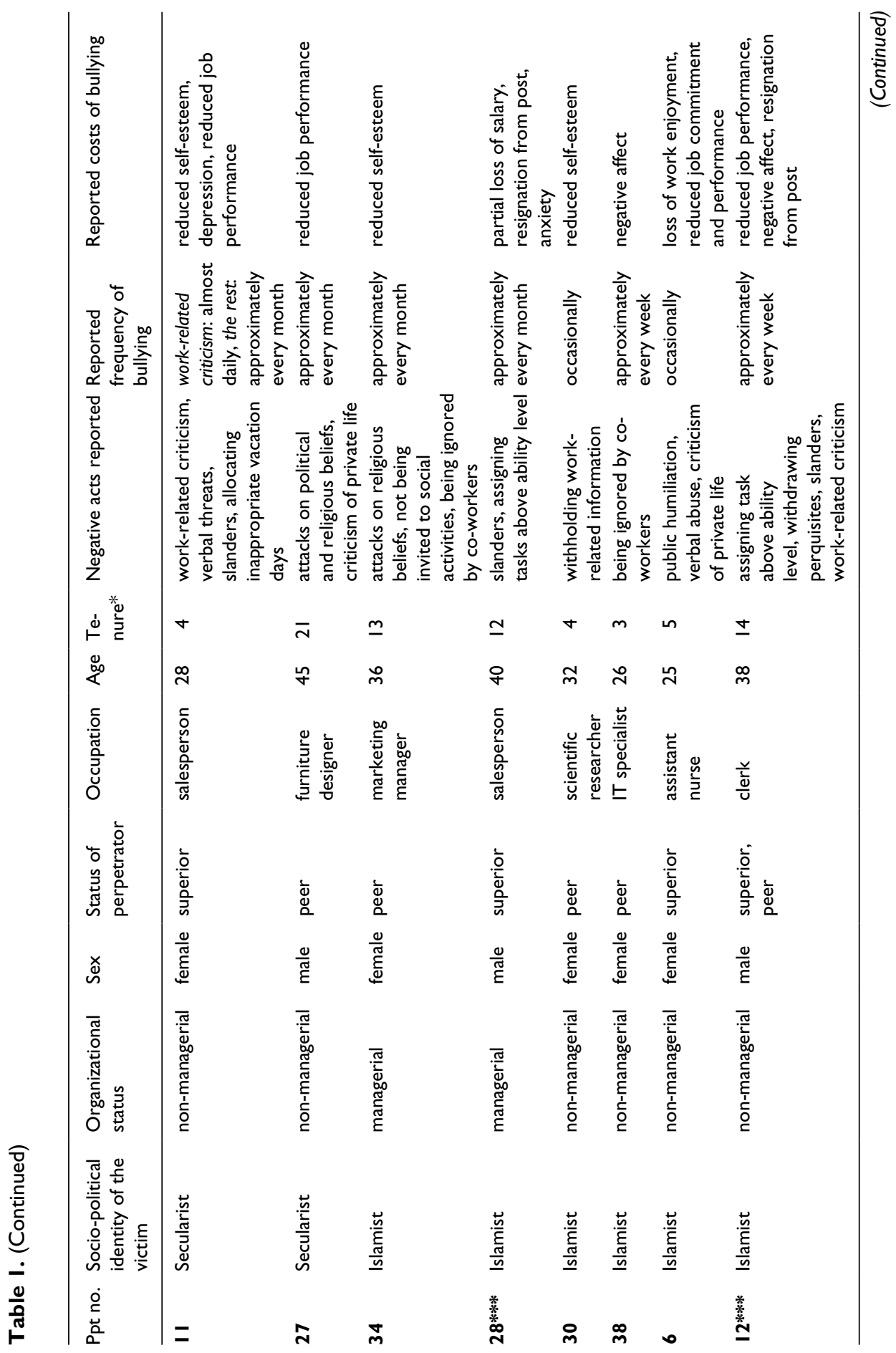




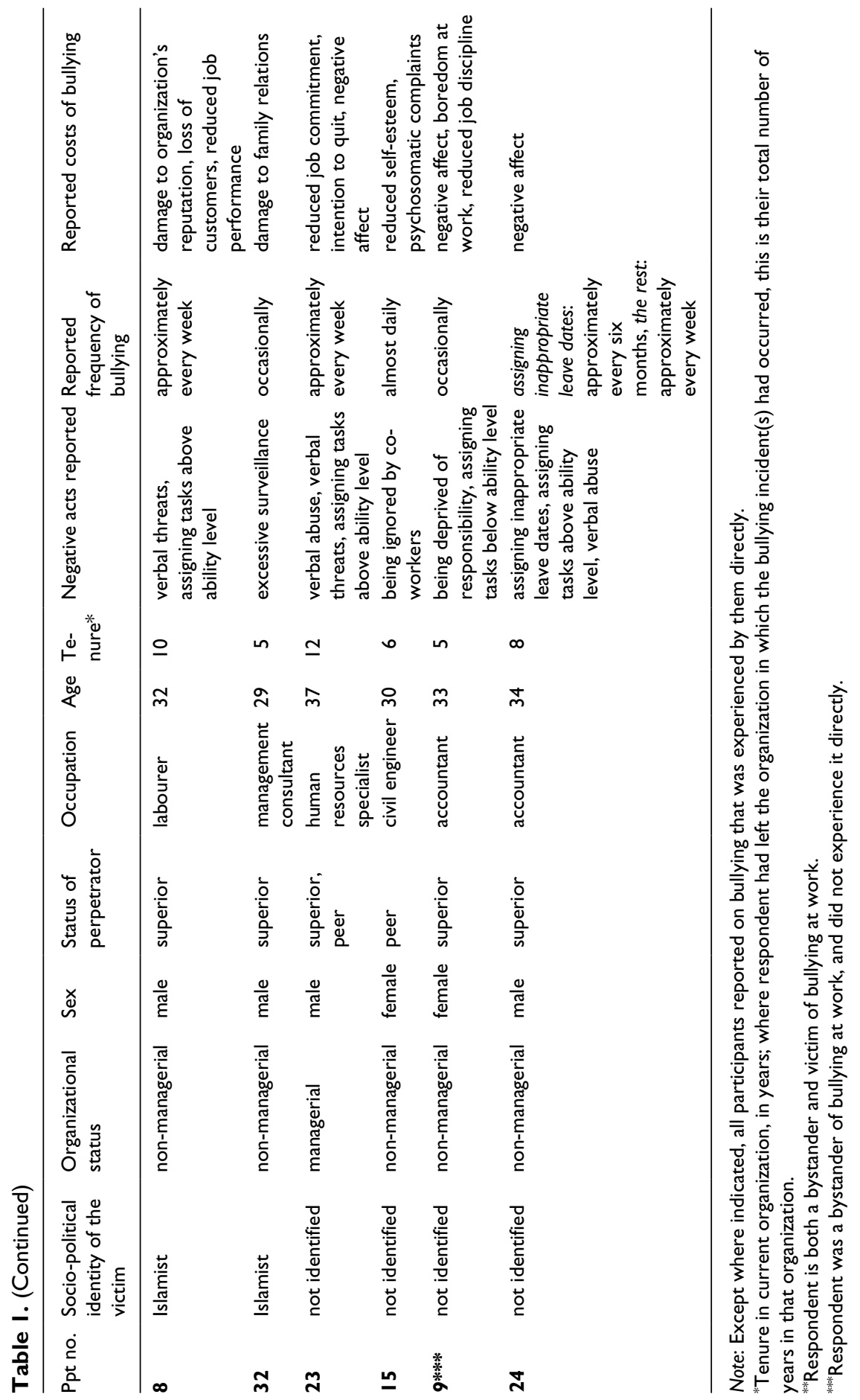


to English, followed by a separate fluent speaker of both languages translating them back to Turkish, the final product yielding a high level of accuracy when compared with the original text.

We employed the 'thematic networks' framework of Attride-Stirling (2001) to analyse the data in a systematic manner, while also adhering to the analysis criteria of Braun and Clarke (2006) and Miles and Huberman (1994). NVivo 9, a computer-assisted qualitative data analysis package, was used for the analysis. Preliminary codes were applied to the textual data to dissect them into meaningful and manageable segments (AttrideStirling, 2001) to facilitate comprehension of the emerging findings. These codes were collated into 'basic themes' and then were revised to be non-repetitive. Following this step, basic themes were collated under 'organizing themes' that reflected a broader level of meaning. In the final step, organizing themes were assembled under 'global themes' on the basis of similarities. Global themes are the core metaphors that encapsulate the main points in the text (Attride-Stirling, 2001).

Complementing the text-driven approach of thematic networks, analysis of the transcripts was also guided by sensitivity to the research questions of interest, namely, to phenomena concerning asymmetric intergroup bullying and the role of wider societal forces in shaping bullying at work. To assess reliability of the coding, a second researcher coded three randomly selected interviews. A 'coding comparison query' was run in NVivo 9, yielding an adequate average percentage of coding agreement (76\%).

The same vividness that allows qualitative analysis to provide a rich picture of a novel phenomenon runs the risk of overweighting the importance of individually striking incidents. Thus, as a final check of the validity of our general conclusions and a test of alternative explanations, we conducted a basic quantitative analysis of appropriate parts of the interview data. We used the summary data from Table 1 to create two coding rubrics to quantify the frequency of each participant's experience of acts of bullying, and the severity of the costs of bullying endured. We present the relationship between scores on these variables and participant background characteristics following the qualitative analysis below.

\section{Analysis}

Table 2 is an overview of the thematic network that arose from our analysis, showing how chunks of text were recorded as basic codes, which were in turn grouped under basic themes, organizing themes and global themes. Examples of each code are also provided.

We began our analysis by considering whether understandings of bullying in the Turkish workplace differ across the two sociopolitical groups of interest. Our findings suggest that they do not: both Islamist and secularist respondents produced similar definitions of bullying and acknowledgement of its negative consequences. When asked, 'What does bullying at work mean to you?', participants described the phenomenon as targeted, systematic behaviours that have destructive consequences for the victim and/or the organization. For both Islamist and secularist employees, stated costs of bullying included poor morale, stress, lowered self-esteem, reduced job satisfaction and intention to quit. As can be seen in Table 1, many participants reported ways in which bullying had directly 
Table 2. Examples of coding and thematic network diagram for the nature and motives of workplace bullying.

\section{Global theme I: Getting rid of unwanted personnel \\ Organizing theme I.I: Private sector bullying to induce uncompensated resignations}

\section{Basic theme: Task pressures}

Basic code: Assigning tasks above ability

e.g. 'By assigning work that is beyond what he can handle, they signal to the person to "quit" his job ... My poor colleague will sure continue to experience such bullying until he quits ... severance pay is the key aspect of bullying.' (Participant 17, secularist, private sector)

Basic code: Excessive surveillance

e.g. 'My superiors do watch almost every step of mine. It feels like pairs of eyes are attached to my office door ... I l am pretty sure they are doing these nasty things in order to make me "escape" from the company screaming!' (Participant 32, Islamist, private sector)

\section{Basic theme: Inappropriate allocation of job benefits (in private sector)}

Basic code: Withdrawing benefits or perquisites (in private sector)

e.g. If companies cannot fire an unwanted employee, if it is against the law, then they start using deterrence policies to get rid of him or her. These abusive policies may involve ... demanding performance that is above your capabilities or withdrawing several perquisites that you are entitled to.' (Participant 12, Islamist, private sector)

Note: The part 'demanding performance that is above your capabilities' in above quote was coded under the preliminary code 'Assigning tasks above capacity (in private sector)'

Basic code: Inappropriate annual leave arrangements

e.g. 'Bullying is used as a means to get rid of employees without offering severance pay. For instance ... companies do not let you arrange annual leave on the dates you want.' (Participant 24, not politically identified, private sector)

\section{Basic theme: Targeting reputation}

Basic code: Slanders

e.g. 'In order not to give severance pay to my colleague, our manager made allegations against him. He even used false witnesses to accuse him ... These allegations were persistent until my colleague resigned.' (Participant 28, Islamist, private sector)

Basic code: Persistent work-related criticism

e.g. 'My manager sees only the negatives ... [He is] never constructive, always being destructive, always criticizes my efforts at the workplace ... My co-workers no longer respect me. Day by day I am moving towards resignation.' (Participant II, Secularist, private sector)

Basic code: Public humiliation

e.g. 'Since I rejected the request of my manager to resign from my job, l've been humiliated by my manager in front of my colleagues. He uses very nasty language while doing that.' (Participant 2I, Secularist, private sector)

\section{Basic theme: Verbal abuse}

Basic code: Aggressive censure

e.g. 'I don't know how long I can resist quitting my job. My line manager tells me off each time he sees me in his room ... It's been a while working in this firm and I do not want to lose my severance pay. That's why I try to resist such abusive behaviours.' (Participant 23 , not politically identified, private sector)

Basic code: Insulting e.g. 'What nasty supervision ... What should I say? Many instances I remember. "Idiot, can't you stop arriving late? Even morons can do this job better ..." This is the language that my boss uses ... I am pretty sure he is that nasty because the money I will get if they kick me out scares them.' (Participant 6, Islamist, private sector) 
Table 2. (Continued)

Basic code: Verbal threats

e.g. 'My superiors frequently tell me "leave the organization or we'll make your days at work really unpleasant for you".' (Participant II, Secularist, private sector)

\section{Organizing theme I.2: Public sector bullying to allocate positions along party lines}

\section{Basic theme: Targeting status}

Basic code: Deprivation of responsibilities

e.g. 'As the conservatives came to power, they thought I am a Communist or an atheist. Therefore, they took away my supervisory responsibilities . . I am a target of bullying since I am not Islamist.' (Participant 20, Secularist, public sector)

Basic code: Removal of supervisees

e.g. 'After the elections, the newly elected mayor took all of my subordinates and replaced them with Islamists in order to put me in a really difficult situation ... I ended up retiring early as I couldn't stand such bullying tactics.' (Participant 19, Secularist, public sector)

Basic code: Assigning inappropriate tasks

e.g. 'I am an auditor who had worked for years as the head of the auditing department here. When they [Islamists] came, they appointed me as the "sports advisor". . . After a while they appointed me as a law advisor. Then another ridiculous position, and so on ... I think in the end l'll retire.' (Participant, 16, Secularist, public sector)

\section{Basic theme: Inappropriate allocation of job benefits (in public sector)}

Basic code: Withdrawing benefits or perquisites (in public sector) e.g. 'As I had been appointed during the ANAYOL [secularist coalition] government, the newly appointed manager did not want to work with me. In order to force me to retire, I was asked to leave the accommodation that was provided by the organization ... Later, my car which had been given by the company was taken back.' (Participant 19, Secularist, public sector)

Basic code: Removal of essential work facilities

e.g. 'Three of us even used only one chair for a while! . . Another time, they deliberately allocated only seven chairs for ten of us ... I am a target of bullying since I am not Islamist.' (Participant, 20, Secularist, public sector)

\section{Global theme 2: Achieving sociocultural dominance at work Organizing theme 2.I: Belief and identity-oriented bullying Basic theme: Attacks on religious identity}

Basic code: Criticizing religious beliefs

e.g. 'My colleagues often question why we serve wine during some of our rituals. Although I have told them that I am not happy to talk about our religious practices, they continue to "dig".' (Participant 5, Secularist, public sector)

Basic code: Dictating Islamic practices

e.g. 'Employees who are not religious are subjected to various negative acts. Employees like me who are not practicing are assertively persuaded to attend prayers.' (Participant 18, Secularist, public sector)

Basic code: Criticizing private life e.g. 'I am really sick of being criticized about being single. My not-so-religious peers should understand that this is my preference. I don't like flirting with others. This is silly.' (Participant 33, Islamist, private sector) 
Table 2. (Continued)

\section{Basic theme: Attacks on political identity}

Basic code: Criticizing political views

e.g. 'Since my colleagues knew that I was leftist, I received a lot of negative remarks regarding my political views. My superiors, my peers and even my subordinates implicitly or explicitly criticized my political views.' (Participant 26, Secularist, public sector)

Basic code: Belittling remarks on political views

e.g. 'They [Islamists peers] often tell me things like "anyone who believes in leftist ideology is a loser for sure”. I find such remarks so humiliating.' (Participant 4, Secularist, public sector)

Basic code: Criticizing worldviews

e.g. I have quite different views about how things should work in a society compared to those of my colleagues. They persistently criticize me about my views. I find it abusive as they never stop.'

(Participant 26, Secularist, public sector)

\section{Basic theme: Attacks on ethnicity}

Basic code: Making ethnic jokes

e.g. 'Currently, I have been subjected to ethnic jokes regarding the Alevi lifestyle.' (Participant 5,

Secularist, public sector)

Basic code: Criticizing background

e.g. 'A couple of my co-workers keep criticizing my origin. For instance, sometimes they even argue that Balkan Turks are half-blooded.' (Participant, 2I, Secularist, private sector)

\section{Organizing theme 2.2: Socially isolating victims at work}

\section{Basic theme: Peer-driven isolation at work}

Basic code: Not inviting the victim to social activities

e.g. 'Someone who does not consume alcohol for religious reasons can be perceived by a not so religious group as an alien who came from outer space... This is something I have experienced since I got this job. I believe I'm not invited to work-related dinners or social activities for this reason.' (Participant, 34, Islamist, private sector)

Basic code: Not replying to the victim's emails

e.g. 'My peers never reply to my emails ... I always sit alone during lunch. Sometimes I feel like I don't exist. Do I need to be one of them? Do I have to fast during Ramadan?' (Participant 3, Secularist,

public sector)

Basic code: Not greeting the victim

e.g. 'My peers never reply to my emails. I do not receive greetings from them.' (Participant 3,

Secularist, public sector)

\section{Basic theme: Management-driven isolation at work}

Basic code: Ordering the victim to work on own

e.g. 'I am no longer a part of any teamwork since the Islamist manager became my boss. I find it abusive as it makes me feel alone at work. Nevertheless, I will never be one of them [Islamists].'

(Participant, 19, Secularist, public sector)

Basic code: Ordering the victim to work away from co-workers

e.g. 'My desk was allocated to the ground floor ... Since then I have felt so lonely at work ... I suspect all these things happened to me as I am the only non-Sunni employee here.' (Participant, 3I, Secularist, private sector) 
impeded their career advancement and economic outcomes, such as through impaired job performance, loss of salary and decisions to resign from the job or to retire early.

The most striking unifying theme was the extent to which bullying in Turkish workplaces was presented as being used instrumentally to achieve organizational and societal goals. None of our participants described incidents of bullying that occurred merely because of individual-level attitudes, traits or other personal reasons. Rather, they described it as a tactic used strategically to achieve goals originating beyond the individual perpetrators. Despite this broad consensus across Islamist and secularist respondents as to the instrumental nature of workplace bullying in Turkey, the precise goals that bullying was claimed to serve, and the severity of the tactics used to fulfil these goals, were presented differently from the perspective of each sociopolitical group. In the following paragraphs, we present such accounts under the major themes that emerged in our analysis.

Two global themes regarding participants' views on the motives and nature of bullying at work were identified. The first global theme to emerge was 'getting rid of unwanted personnel', referring to institutionalized bullying that is coldly instrumental in nature, designed to change the allocation of roles and the composition of the organizational workforce. The second global theme was 'achieving sociocultural dominance', referring to the use of bullying practices to advance potent social and cultural themes from the wider society. Complementing the information in Table 2, we discuss each global theme in turn, along with sub themes and participant quotes to show how the themes were developed.

\section{Global theme I: Getting rid of unwanted personnel}

Almost all of our respondents pointed to common, routinized and instrumental bullying practices used in Turkish private and public sector organizations to get rid of unwanted personnel. However, the reported underlying motivations for discarding unwanted staff differed with respect to the two sectors from which we sampled. In the private sector, the major reason cited for engaging in targeted negative acts was to cause employees deemed unproductive or redundant to resign, thus disqualifying them from the receipt of severance pay. In the public sector, on the other hand, respondents stated that top management aimed to get rid of personnel whose ideology differs from that of the current ruling elite.

Organizing theme I.I: Bullying in the private sector to induce uncompensated resignations. As severance pay must be awarded to those who are dismissed after working for an organization for more than six months, some participants argued that private sector firms who want to get rid of established workers may try to pressure them to resign. As a tactic to achieve this, both Islamist and secularist participants described bullying directed from management towards personnel deemed unproductive or redundant in a company, regardless of their sociopolitical orientation.

As can be seen in Table 2, Participant-12, who works in the private sector, stated that several task-related bullying acts, such as exposing victims to an unmanageable workload or withholding benefits, were frequently used by employers or managers in private sector companies to pressure unwanted employees into leaving their job. 
Participant-24, also from the private sector, argued that arranging inappropriate annual leave is another tactic used in Turkish companies to pressure employees to resign (see Table 2). Participants also stated that private sector employees with supervisory responsibilities used verbal abuse, public humiliation and slander in a similar way. For instance, one participant complained about the situation at work that her advanced age put her in:

I think they [management] see me as a granny who has to be sacked . . There is no tolerance, not any more ... For instance, in a metropolis like Istanbul, it is quite challenging to be at work on time. However, even arriving two or three minutes late would be a catastrophic event according to the principal. Each morning that I arrive just a few minutes late, she uses nasty language and yells at me. (Participant-17, senior teacher, private sector, secularist)

This instrumental form of bullying was reported both by employees directly targeted by it and by those who observed it affecting their colleagues (see e.g. Participant-28 in Table 2). Thus, bullying was presented as a common management practice in Turkish private sector organizations, used in order to subvert legislation meant to protect Turkish employees.

Organizing theme 1.2: Public sector bullying to allocate positions along party lines. Unlike in the private sector, participants stated that avoiding severance pay is not a motivation behind bullying in the public sector since the government meets such severance costs. Yet participants working in the public sector did report the instrumental use of bullying to get rid of unwanted personnel: in this case, unwanted by virtue of their sociopolitical allegiance. That is, both Islamist and secularist employees acknowledged that new, Islamist (pro-AKP) managers in the public sector were targeting negative treatment towards senior personnel appointed by the previous, secularist government, in order to get them to resign or retire. As can be seen in the quotes in Table 2 and below, participants indicated that such pressure can be exerted by withdrawing essential work facilities or removing key responsibilities:

As the conservatives [the AKP] came to power, they thought I am a Communist ... Therefore, they took away my supervisory responsibilities. They did not give me any substantial tasks. They even took my room. Three of us even used only one chair for a while! . . Another time, they deliberately allocated only seven chairs for ten of us. (Participant-20, engineer, public sector, secularist)

Participant-20, who had served in the public sector as a supervisor, stated that he retired and became self-employed after the incidents he experienced. Another interviewee, Participant-19, who had worked for over 25 years in the public sector, stated that she tried to resist the bullying directed at her by her new Islamist-leaning superiors because she was appointed during the previous government. However, following persistent withdrawal of her benefits and replacement of key areas of responsibility with more trivial tasks, she retired a couple of months after the appointment of the new department 
head. In total, as a direct result of workplace bullying, three participants from our public sector sample $(n=19)$ reported leaving their job, and six reported an intention to quit. All of them were from the sociopolitical group that was out of power at the time the bullying occurred.

It should be noted that almost half of Islamist participants also acknowledged the pressure and mistreatment currently being directed towards public sector employees who had been appointed during the pre-AKP period. However, Islamist respondents did not provide specific examples of such bullying incidents, suggesting that they were judged by them as less serious. While acknowledging institutionalized bullying that secularists are experiencing in the public sector, Islamist participants also cited bullying that Islamists had experienced before AKP rule:

Ten years ago, there was bullying of the secularists on us. I witnessed that. 'I am [secularists] the real owner of Turkey, you are [Islamists] someone who tries to spoil the system, so stay away from this organization!' [This] type of bullying has now turned into 'now I am [Islamists] dominant in this organization'. (Participant-36, teacher, public sector, Islamist)

Likewise, Participant-35 stated that before AKP rule, Islamists were under heavy pressure in public sector organizations. This participant also acknowledged the shift in intergroup dominance at work that came about during AKP rule:

I think the roles have changed. Now the public sector is under the domination of the conservatives. Now the Islamists are pressuring and discriminating the other group ... They are now, somewhat saying 'now it's our turn!' People call it like 'revenge', revenge for February $28^{\text {th }}$ [date in 1997 of a military-driven move to repress Islamists]. (Participant-35, researcher, public sector, Islamist)

\section{Global theme 2: Achieving sociocultural dominance at work}

The use of bullying to get rid of unwanted personnel is a particularly calculated practice, designed, according to our respondents, explicitly to advance the interest of an organization, in the case of the private sector, or a sociopolitical group, in the case of the public sector. The second goal towards which bullying practices were used is less tangible and thus possibly less consciously mobilized, but is no less pernicious. All of our participants agreed that the polarized nature of Turkish society was evident within Turkish organizations in the interpersonal interactions between members of opposing sociopolitical orientations. In particular, negative treatment across group lines is presented as a method to achieve the sociocultural dominance of one or other of the two competing social groups.

Though there was consensus as to the divisive nature of Turkish politics and public discourse, we heard competing accounts from each sociopolitical side as to its origin and future direction. Interviewees who identified as secularists claimed that the country under AKP rule was moving in the direction of an authoritarian regime, whereas most government supporters argued that a genuine process of enlightenment and democratization was taking place in Turkey: 
With the foundation of Turkish republic, a systematic policy had been issued to make people forget their religion. After some decades, they began to ask themselves 'Why do I not experience it openly [Islam]?' . . . After some time the youth has begun questioning this suppression. I mean they have begun to live it [Islam]. (Participant-34, marketing manager, private sector, Islamist)

Given the supremacy of the AKP in the Turkish political scene, and the increasing dominance of public sector organizations by the party's supporters, reports of socioculturally-themed bullying practices were particularly acute when secularist employees were targeted. Many participants claimed that Islamists within Turkish organizations are currently attacking the beliefs and identity of their secular co-workers, or socially isolating them at work in order to demean their cultural position. The same participants argued that these incidents led to polarization in the workplace and the alienation of secularist victims targeted by bullying.

Organizing theme 2.I: Belief and identity-oriented bullying. A portion of our participants claimed that some supporters of the current ruling party in management positions continuously pressured employees who have contrasting religious beliefs:

You should attend Friday prayers or be fasting during Ramadan in order to be one of 'them'. Otherwise, you will be excessively criticized for your views and then end up being appointed to work in very remote offices. (Participant-16, auditor, public sector, secularist)

Although the lines dividing groups in work are sociopolitical, participants described how ethnic and religious sect identities were used as an indirect means of targeting members of the opposing coalition. As can be seen in the following quote, Participant-5 argued that her Islamist peers at work persistently make implicit offensive remarks regarding her Alevi ethnicity and religious views:

My colleagues often question why we serve wine during some of our rituals. Although I have told them that I am not happy to talk about our religious practices, they continue to 'dig'. Once, they even told me that the mayor of Istanbul should rename Gazi [Alevi] District as 'Yavuz Sultan Selim' [name of sixteenth century sultan known for his massacre of Alevis] District! ... (Participant-5, bank officer, public sector, secularist)

Participants claimed that attacks on beliefs also included criticism of political views. In Table 2, this can be seen in the extract from the interview with Participant-26, who was a secularist working in a public high school in which the majority of the teachers were supporters of the AKP.

Likely because of its sociopolitical tone, reports of verbal abuse relating to beliefs and identity are more frequent in Turkish public sector organizations than in the private sector. Twelve (out of 19) public sector employees in the sample reported that attacks on beliefs and identity are common problems in their organizations, and that it was secularists who were most often the targets of bullying at work. In contrast, only three examples of such negative acts were reported by private sector employees $(n=19)$ and, when this happened, it occurred in private sector organizations that have strong connections with 
the ruling party. For instance, Participant-25, who experienced criticism of his religious views at work, described the owner of the factory in which he worked from 2003 to 2006 as highly religious and an AKP supporter:

My boss tried to force me to attend Friday prayers. However, I resisted attending. I experienced frequent insulting remarks made about my religious beliefs. I was even told that I am a sinful person! (Participant-25, industrial engineer, private sector, secularist)

Secularist participants argued that they had not experienced criticism at work of their political or religious views before the AKP came to power. However, participants who identified as Islamist stated that they had experienced attacks on their beliefs when secularists were the dominant group in Turkey. An example of such incidents was provided by a participant who works as a specialist in a Turkish public hospital:

During the mid-90s, like my religious colleagues in other public firms, I was oppressed at the workplace. Our clinic chief continuously bullied me at work, mostly by questioning my worldview ... she often criticized my wife's decision to wear a headscarf, [and] encouraged my subordinates to spread rumours that I am an Islamic fundamentalist. She indeed behaved as 'the secularism police' at the hospital. (Participant-29, surgeon, public sector, Islamist)

Participant-29 stated that since the AKP came to power in 2002, such bullying attempts in the public sector have decreased gradually and are no longer a threat, putting this down to the democratization policies of the AKP government.

Organizing theme 2.2: Socially isolating victims at work. Ostracism emerged as the second major theme under the global theme of achieving sociocultural dominance. Our findings suggest that polarization between secularist Turks and supporters of the current ruling party may lead to the social isolation of those who are in the minority in a particular workplace. As can be seen in Table 2, Participant-3 (a public sector employee), indicated that in workplaces where secularist employees are a minority, they may be ostracized by proponents of the ruling party. This respondent had been a middle-manager in a Turkish public organization since 1987, but her managerial status was not sufficient to prevent her from being bullied. She reported that all of her colleagues who were appointed by the former ruling party had either resigned or had been appointed to rural regions of Turkey, to pressure them to resign. As her colleagues left, she became a minority in her workplace, and thus a target for mistreatment.

Also observable from Table 2, secularist participants, such as Participant-31, who had obtained her job during a pre-AKP government, claimed that they are ordered to work away from co-workers. In this case, being non-Sunni was a cue to Participant-31's sociopolitical identity, as almost all Islamists in Turkey are Sunni Muslims (Verkuyten and Y1ldız, 2006).

In private sector organizations, in which secularists might be in the majority or in positions of power, some Islamist participants stated that they or other Islamists were the victims of bullying at the hands of their secularist colleagues. Specifically, Islamist participants reported that secularist colleagues at work limited their contacts with them because Islamists do not drink alcohol. The interview extract from Participant-4 in Table 2 contains an example of this type of peer-driven isolation at work. 
Islamist participants in our study also argued that their secularist co-workers socially isolate them if they want to perform prayers at work. For instance, Participant-38, an Islamist who works in a corporation that mostly employs secularists, reported being ostracized after she demanded a prayer room in the workplace. This participant also noted that recently her request had been accepted and the firm introduced a prayer room for practicing employees. She claimed it was the rise of the AKP that may have led the management to respond to the demands of Islamist employees more fairly. While some ongoing bullying against Islamists was reported, there was no evidence from Islamist participants that the social isolation they were experiencing in secularist-dominated private sector companies was used instrumentally to encourage lifestyle changes or to pressure them to resign. In fact, one Islamist participant stated that her manager often reminds her that as long as she performs her job properly, she can stay in the firm despite being an Islamist.

\section{Quantitative analysis}

The above qualitative analysis indicates that the severest forms of bullying reported were those involving the instrumental use of bullying tactics by supporters of the current Turkish ruling party to upset the stability and advancement of supporters of the previous ruling party, particularly in the public sector. To assess the validity and robustness of this pattern, we conducted a rudimentary quantitative analysis of relevant parts of the text corpus.

Using Table 1 as our foundation, we created a five-point Likert scale variable, frequency of bullying incidents $(0=$ almost never; $1=$ occasionally; $2=$ about once a month; 3 = about once a week; 4 = about once a day; 5 = multiple times per day), and a ninepoint Likert scale variable, economic severity of greatest bullying cost $(0=$ no consequence reported; 1 = decreased job enjoyment; $2=$ negative affect, psychosomatic complaints, poor self-evaluation; $3=$ reduced job commitment/desire to quit; $4=$ reduced job performance; 5 reputational damage; $6=$ impaired career development/loss of promotion opportunities; $7=$ partial loss of salary; $8=$ early retirement; $9=$ resignation from post). The latter variable was designed to represent the extent to which the bullying endured had led to consequences for the victim that might impinge on their economic outcomes. As such, high figures on this variable were allocated to victims who endured the direct disruption of job advancement and tenure, while low figures were allocated to those who experienced only reduced job enjoyment or negative emotions.

One participant was excluded from the analysis for reporting on bullying experiences that took place in a period before AKP rule. We first found a marginally significant trend indicating that the greater the frequency with which one was bullied, the greater the economic costs one endured: $r(37)=.32, p=.06$. About equal numbers reported being targeted by a superior $(n=23)$ as by a peer $(n=21)$, and neither frequency nor cost severity varied with the status of the perpetrator.

We then conducted a one-way ANOVA with political affiliation (Secularist, Islamist, or Not Identified) as a fixed factor, to see if the disproportionate targeting of secularists highlighted by our thematic analysis held across the sample. There was indeed a significant effect of political affiliation on frequency of bullying experienced: $F(2,34)=7.95$, 
$p=.001$. Planned contrasts revealed that identifying as a secularist was associated with experiencing greater frequency of bullying than professing an Islamist or no political affiliation $(t[34]=-3.05, p=.004)$, with no difference in amount of bullying experienced between the latter two categories $(t<1.7)$. This pattern held for the severity of economic costs of bullying: $F(2,34)=5.93, p=.006$, with secularist bullying victims also enduring worse consequences than Islamists or non-identifiers $(t[34]=-3.43, p=.002)$, and no difference in costs between the latter groups $(t<0.6)$. In contrast, there were no significant differences in the frequency of bullying endured according to the gender, education, age, managerial status, or organizational tenure of the respondent, nor in the economic costs of bullying on the basis of gender or education. Those who were older $(r[37]=.49$, $p=.002)$, longer in the organization $(r[37]=.51, p=.001)$, and held a managerial status $(t[35]=-2.02, p=.05)$ suffered greater career-related costs from bullying, likely reflecting the fact that the stakes are higher at higher levels of an organization. Putting gender, education, age, managerial status, organizational tenure and dummy variables for political identity (reference group $=$ Islamist) into two linear regressions revealed that only political identity stood as a significant predictor of both frequency $\left(\beta_{\text {secularist }}=0.59, t=\right.$ $2.96, p=.006)$ and economic costs $\left(\beta_{\text {secularist }}=0.40, t=2.29, p=.03\right)$ of bullying reported.

We then conducted $2 \times 2$ ANOVAs with simple effects analyses among those who expressed a political affiliation (i.e. leaving out the group with no political identification), to examine whether the pattern of differential experiences of bullying by sociopolitical orientation in turn depended on the sector in which a respondent's organization was based. Again, in line with insights from the qualitative analysis, there was a marginally significant interaction between political identity and sector in predicting bullying frequency: $F(1,27)=3.01, p=.09$. Whereas only a marginally significant increase in the bullying of secularists versus Islamists was reported in the private sector $(F[1,27]=4.17$, $p=.05$ ), a highly significant increase in the bullying of secularists versus Islamists was reported in the public sector: $F(1,27)=19.04, p<.0001$. A similar analysis for the economic costs of bullying demonstrated this pattern even more starkly. Here, an interaction between political identity and sector $(F[1,27]=6.53, p=.02)$ broke down into an absence of sociopolitical differences in the costs of bullying in the private sector $(F=.08)$, but a large increase in the severity of the costs of bullying of secularists versus Islamists in the public sector: $F(1,27)=14.45, p=.001$.

\section{Discussion}

We brought a wider societal lens to the phenomenon of workplace bullying, an extreme case of dysfunctional organizational behaviour that causes severe harm in its victims, and yet is difficult to stamp out. Introducing the concept of asymmetric intergroup bullying, we used social structural theories to understand how it might be shaped by the dynamics of inequality in the society in which an organization is embedded. Taking Turkey as a context in which such dynamics are particularly potent, we presented interview data on the nature, antecedents and costs of bullying as it is reported by public and private sector employees from a range of backgrounds.

Their reports paint a picture of bullying as deployed strategically, to achieve goals beyond those of the perpetrators themselves. Respondents portrayed bullying used either 
as a calculated means of getting rid of unwanted employees, or as a subtle, but no less pernicious, means of achieving the dominance of one sociocultural worldview over another. Thus emerges a picture of bullying as a manifestation of processes of sociopolitical conflict and inequality, and, in turn, a mechanism through which such inequality is maintained and reproduced.

The first way in which bullying was framed was as a set of abusive management practices targeting specific individuals in order to induce them to leave an organization of their own accord. Respondents from across the political spectrum and across industry sectors reported on superiors' use of impossible work demands or public humiliation to target unwanted employees. As described in the private sector, such bullying practices are used to avoid the financial costs of firing workers deemed unproductive, making this a case of instrumentalized bullying (Salin, 2003a) that achieves an organizational rather than an individual goal.

Accounts of bullying as motivated to induce organizational departure are even more startling when they are described in the public sector. Here, according to our secularist, and even some of our Islamist, respondents, such abuse of power is targeted towards employees by virtue of their sociopolitical affiliation; it is a means for newly appointed Islamist managers to induce secularist employees to leave their jobs. One might interpret this on one level as an attempt by managers to achieve value congruence within the organization, a goal often cited as desirable in organizational behaviour research (Erdogan et al., 2004). On another level, however, the dynamics of the Turkish sociopolitical context suggest that such bullying practices are being used instrumentally to achieve goals extending beyond the organizations concerned. Secularist, and even some Islamist, accounts of the nature of public sector bullying of secularist employees were deeply strewn with references to attempts to get victims to leave their powerful positions so that those positions can be filled by supporters of the ruling party, thus strengthening their hand in society at large. The practices thus qualify as cases of asymmetric intergroup bullying, a conclusion that is consistent with the reported trends towards growing societal dominance of political Islamism in Turkey at large (Toprak et al., 2008). This is also borne out in our quantitative analysis of the incidence of bullying, showing that the dimension that best predicts the amount of bullying one receives is sociopolitical, that secularists are the group suffering the greatest frequency of bullying, and that the latter was especially the case in the public sector.

Once the societal nature of the underlying roots of bullying in this politically charged national context is exposed, consequences of bullying that appear at the individual level can be seen to have downstream effects that are much more profound. In the context studied here, if it is the case that secularists not only suffer more bullying than Islamists, but also suffer greater career-related costs of bullying, then secularists as a group will exhibit more decrements in job performance, barriers to advancement, reputational damage and pressures to leave an organization, than Islamists. Supportive of this claim, quantitative evidence that secularists in the public sector are the ones whose economic well-being is the most severely affected by bullying supplemented vivid qualitative accounts of bullying victims being worn down to the point of organizational departure. Whether this will translate into differential economic outcomes at the intergroup level requires noting that though Turkey's economy under AKP rule first saw a decrease in 
income inequality (Turkish Statistics Institute, 2012), as the low-earning electoral base of the party saw their situations improve (Hazama, 2009), a large portion of the substantial economic inequality that persists is due to the disparity in wages between legislators, senior public officials and managers, at the top, and the rest of the occupational distribution (Oskoc et al., 2011). If, as is claimed by political and economic analysts (Cengiz and Hoffmann, 2012; Hoşgör, 2011), such senior positions are increasingly occupied by Islamists, then the spread of the asymmetric intergroup bullying reported in this article may contribute to a marked increase in the income of Islamists at the top of society, at the cost of secularists. In that case, regardless of the overall level of income inequality in Turkey, the distribution of income across sociopolitical groups may become increasingly skewed. Future investigations of bullying as a strategic weapon used for societal purposes should directly assess its effectiveness as a social dominance strategy, exacerbating the asymmetric allocation of economic resources to different societal groups.

The second global theme to emerge from our data cements the impression that the dynamics of societal intergroup inequality are playing out in Turkish workplaces in the form of bullying. This theme dealt with bullying that was not only vertical, from supervisors to employees, but also horizontal, among peers. It contained accounts of employees having their political and religious views criticized by their co-workers, the mocking of ethnic identities linked to an opposing sociopolitical identification, and identity-based ostracism from workplace social life.

This is a form of bullying to achieve sociocultural dominance over an opposing political group, the direction of which appeared to depend on the composition of the organization concerned: secularist-dominated organizations featured the verbal bullying of Islamists, and Islamist-dominated organizations featured the verbal bullying of secularists. Nevertheless, there were a greater number of incidents in which secularist (as opposed to Islamist) employees reported being targeted because of their political or religious views and habits, and such incidents were described as more severe than when Islamists were targeted. Coupled with the increasing influence of Islamists in public and private sector organizations (Hoşgör, 2011; Toprak et al., 2008), our data imply that the net societal effect of socioculturally-oriented bullying across Turkish organizations is to enhance an existing asymmetry in the external political conflict. This cements the impression that the sociocultural ascendancy of Islamists in all aspects of Turkish life (Toprak et al., 2008) is playing out in the Turkish workplace, in sharp contrast to the suppression of religion and religiosity before the AKP came to power (Başkan, 2010).

Bullying as a means to achieve sociocultural dominance is of relevance beyond the Turkish context, however, as it can apply to any country in which coalitional divides are mirrored by differences in appearance, beliefs and lifestyle. In addition to affecting intergroup economic inequality via career-relevant employee behaviour (see Hoel et al., 2011; Lim et al., 2008), socioculturally-oriented workplace bullying might feed into wider inequalities by subtly changing the way all members of different groups are perceived. It does so partly by strengthening consensual stereotypes about the relative worth of groups with different levels of power in an organization, thus feeding into the devaluation of the social identity of bullying victims within society at large. Such status construction processes (Ridgeway, 1991; Ridgeway and Balkwell, 1997) arising from workplace bullying may be an important channel through which the asymmetric 
intergroup capture of political and economic resources is achieved (Sidanius and Pratto, 1999).

\section{Theoretical and practical implications}

The severity of the acts reported in this study stands out from previous studies of bullying in the USA and Europe (Einarsen et al., 2011). Part of this may come down to features of the Turkish human resources infrastructure, such as an absence of established anti-bullying legislation and reporting procedures (Aycan, 2001), or a national business scene that has been characterized by opportunism and poor ethical values (Buğra, 1994). However, given that regulations concerning severance pay are a feature of almost all industrialized countries (International Labour Organisation, 2012), and that the corporate gaming of regulations is an increasingly troublesome issue in the USA (Salter, 2010), there is good reason to believe that instrumentalized bullying of this kind may be found in many more developed countries. The possibility of using indirect hostility to get around regulations implies that even stronger anti-bullying legislation may fall short of ending this pernicious phenomenon. Other factors, such as the weakness of Turkey's trade unions - bodies that play an important role in combating bullying in other countries (Hoel and Beale, 2006; Sheehan et al., 1999) - are also pertinent to contexts such as the USA, in which collective bargaining is constantly under threat (Slaughter, 2007). Seen in this light, strengthening trade unions and developing a strong culture of human resources management may help to create a climate in which mistreatment or targeted incivility among employees is not tolerated (Rayner and Cooper, 2006).

Even taking these factors into account, however, one cannot ignore the role played by macro-political and social tensions in corrupting management practices and peer interactions. Without consideration of, for example, external societal factors intergroup contact theory might predict that workplaces with a heterogeneous set of employees should enhance intergroup relations, as they feature the common goal and authority endorsement entailed by working for the same organization, and the acquaintance potential provided by daily co-location (Allport, 1954; Brown and Hewstone, 2005). However, insights from conflict theories of inequality remind us that even employees who are equal in status within an institution may nevertheless be markedly different in status in the wider society, and that institutional dynamics will reflect those societal inequalities (Côté, 2011; DiTomaso et al., 2007; Sidanius and Pratto, 1999). Our description of asymmetric intergroup bullying suggests that, at least in a society with polarizing intergroup inequality, a socially heterogeneous workforce is one in which interactions feature acts of social dominance on a daily basis.

This investigation marks a step forward as the first study not only of the motivations and sociopolitical dimension of bullying in Turkey (though see Soylu, 2011), but of the notion of asymmetric intergroup bullying as a phenomenon observable in any society. We hope that our identification of bullying practices as a set of mechanisms for enhancing intergroup inequality may create a sensitivity that contributes to its reduction. For example, greater accountability of supervisory decisions, and a transparent bureaucratic framework for the allocation of roles, might prevent the abuses of power reported here, and have been shown to combat unequal allocation along group lines in other contexts 
(Blalock, 1991; see Reskin, 2003). Paying attention to the ways in which stereotypes reinforce exclusionary patterns among groups of unequal status (Côté, 2011; Ridgeway, 1991) might also help to improve interactions between employees in diverse settings.

Ultimately, however, the quality and fairness of management practices in public sector organizations, and the nature of social relations among communities in workplaces of all types, will depend heavily on developments in a country's wider sociopolitical context. Our findings regarding the effects of Turkish intergroup inequality on management practice and organizational culture might act as a warning of the corrosive consequences of using bureaucratic positions to solidify the strength of one political or social group over another. The fact that attempts by secularists to dominate all areas of Turkish society in the last century (Arat, 1998) are now being answered by an aggressive inversion of power in political, social and professional realms in favour of Islamists, is in line with Sidanius and Pratto's (1999) claim that the inversion of an intergroup hierarchy will not mark the end of hierarchy itself. To break out of this pattern, a regime can attempt to decouple political power from economic ascendancy, freeing up the public and private sectors to operate on principles of efficiency, merit and fairness rather than sociopolitical concerns. On the other hand, one could argue that any society that has experienced a long history of political and economic asymmetry between social groups risks further entrenching this asymmetry if social group identities are downplayed before the imbalance in income and wealth between them is addressed. Though it sets a difficult task, the lesson for Turkey and other countries is that until inequality and polarization between social groups are addressed, management practice and workplace interactions may continue to display patterns of asymmetric intergroup incivility and mistreatment.

\section{Limitations and future research}

Striking as our findings are, they present a set of empirical limitations and a need for future research to paint a clearer and more robust picture of the phenomena observed. We note that our study adds a much needed qualitative insight into accounts of workplace bullying (Salin, 2003b), in the hope that it might be complemented by more comprehensive quantitative analyses of the mechanisms involved than we could conduct with such a small sample. Though we used a systematic coding and analysis scheme, the interpretation of the data nevertheless maintains a subjective flavour, as is characteristic of qualitative research. Sampling was pursued in a systematic way, but we acknowledge inevitable self-selection issues in a study advertised as concerning workplace bullying, which may have enhanced our impression of its prevalence (De Cuyper et al., 2009).

Finally, research is clearly needed to see whether and if, as predicted, such strategic bullying and sociopolitical dynamics are observed in societies with more developed human resource management systems and a different set of intergroup tensions. Even if structural factors hold across contexts, it may be difficult to generalize from sources of identity that are belief-based, such as religious and political affiliation, to those that are ascribed, such as ethnicity and gender. Indeed, the very fact that membership in the former type of social category is seen as voluntary might increase the potential for one to be 'punished' for one's membership in that category. This is a fruitful question to 
explore in future studies of asymmetric intergroup bullying and workplace diversity more generally.

Despite the intricacies of generalizing from the current set of data, we believe this article opens up a conceptual and empirical space for further explorations of the interface between societal inequality and organizational life. Its insights are equipped to play one small part in helping organizational psychology to take wide-spanning ownership of the pervasive and subtle workings of power, groups and inequality. We at least hope that we have convinced our readers to first take a critical look at the societal context surrounding an organization, before peering inside.

\section{Acknowledgements}

We would like to thank the Special Issue Guest Editors Dr Hari Bapuji and Dr Suhaib Riaz, and the three anonymous Human Relations reviewers for their insighful feedback on this article. We would also like to thank Professor Jim Sidanius, Dr Jan Stockdale, Professor Charlotte Rayner and Mrs Sertaç Sehlikoglu for their constructive comments on an earlier draft of this article.

\section{Funding}

This research received no specific grant from any funding agency in the public, commercial, or not-for-profit sectors.

\section{Note}

1 Both authors contributed equally to this work.

\section{References}

Allport GW (1954) The Nature of Prejudice. Cambridge, MA: Perseus Books.

Arat Y (1998) Feminists, Islamists, and political change in Turkey. Political Psychology 19(1): $117-131$.

Attride-Stirling J (2001) Thematic networks: An analytic tool for qualitative research. Qualitative Research 1(3): 385-405.

Aycan Z (2001) Human resource management in Turkey: Current issues and future challenges. International Journal of Manpower 22(3): 252-260.

Barak ME, Cherin DA and Berkman S (1998) Organisational and personal dimensions in diversity climate: Ethnic and gender differences in employee perceptions. Journal of Applied Behavioral Science 34(1): 82-104.

Başkan F (2010) The rising Islamic business elite and democratisation in Turkey. Journal of Balkan and Near Eastern Studies 12(4): 399-416.

Blalock HM (1991) Understanding Social Inequality: Modelling Allocation Processes. Newbury Park, CA: SAGE.

Braun V and Clarke V (2006) Using thematic analysis in psychology. Qualitative Research in Psychology 3(2): 77-101.

Brown R and Hewstone M (2005) An integrative theory of intergroup contact. In: Sanna MP (ed.) Advances in Experimental Social Psychology, 37. San Diego, CA: Elsevier, 255-343.

Buğra A (1994) State and Business in Modern Turkey: A Comparative Study. New York: SUNY Press.

Çarkoğlu A and Toprak B (2007) Religion, Society and Politics in a Changing Turkey. Istanbul: TESEV Publications. 
Cengiz F and Hoffmann L (2012) The 2011 general elections in Turkey: Potential implications on domestic and international politics in the shadow of a discourse change? Parliamentary Affairs 65(1): 255-269.

Cortina LM, Magley VJ, Williams JH and Langhout RD (2001) Incivility in the workplace: Incidence and impact. Journal of Occupational Health Psychology 6(1): 64-80.

Côté S (2011) How social class shapes thoughts and actions in organisations. Research in Organisational Behavior 31(1): 43-71.

De Cuyper N, Baillien E and De Witte H (2009) Job insecurity, perceived employability and targets' and perpetrators' experiences of workplace bullying. Work \& Stress 23(3): 206-224.

Dipboye RL and Colella A (eds) (2004) Discrimination at Work: The Psychological and Organizational Bases. New Brunswick, NJ: Psychology Press.

DiTomaso N, Corinne P and Rochelle PY (2007) Workforce diversity and inequality: Power, status, and numbers. Annual Review of Sociology 33(1): 473-501.

Einarsen S, Hoel H, Zapf D and Cooper CL (2011) The concept of bullying and harassment at work: The European tradition. In: Einarsen S, Hoel H, Zapf D and Cooper CL (eds) Bullying and Harassment in the Workplace, 2nd edn. Boca Raton, FL: Taylor \& Francis, 3-41.

Ely RJ and Thomas DA (2001) Cultural diversity at work: The effects of diversity perspectives on work group processes and outcomes. Administrative Science Quarterly 46(2): 229-273.

Erdogan B, Kraimer ML and Liden RC (2004) Work value congruence and intrinsic career success: The compensatory roles of leader-member exchange and perceived organisational support. Personnel Psychology 57(2): 305-332.

Ferris GR, Sinko R, Brouer RL, Buckley MR and Harvey MG (2007) Strategic bullying as a supplementary, balanced perspective on destructive leadership. The Leadership Quarterly 18(3): 195-206.

Field T (1996) Bullying in Sight. Didcot: Success Unlimited.

Giga SI, Hoel H and Lewis D (2008) The costs of workplace bullying. London: Unite the Union/ Department for Business, Enterprise and Regulatory Reform.

Glaso L, Matthiesen SB, Nielsen MB and Einarsen S (2007) Do targets of workplace bullying portray a general victim personality profile? Scandinavian Journal of Psychology 48(4): 313-319.

Hazama Y (2009) Economic Voting and Electoral Volatility in Turkish Provinces, No. 202. Institute of developing economies, Japan External Trade Organisation. Available at: https:// ir.ide.go.jp/dspace/bitstream/2344/829/1/202_hazama.pdf, accessed June 2013.

Hoel H and Beale D (2006) Workplace bullying, psychological perspectives and industrial relations: Towards a contextualised and interdisciplinary approach. British Journal of Industrial Relations 44(2): 239-262.

Hoel H, Sheehan MJ, Cooper CL and Einarsen S (2011) Organisational effects of workplace bullying. In: Einarsen S, Hoel H, Zapf D and Cooper CL (eds) Bullying and Harassment in the Workplace, 2nd edn. Boca Raton, FL: Taylor \& Francis, 129-149.

Hoşgör E (2011) Islamic capital/Anatolian tigers: Past and present. Middle Eastern Studies 47(2): 343-360.

International Labour Organisation (2012) Severance pay and redundancy payment. Employment Protection \& Legislation Database (EPLex). Available at: http://www.ilo.org/dyn/eplex/termdisplay.severancePay?p_lang=en, accessed December 2013.

Keyman EF (2010) Modernisation, globalisation and democratisation in Turkey: The AKP experience and its limits. Constellations 17(2): 312-327.

KONDA (2011) Political Tendencies Survey Report. Istanbul: KONDA Research

Lee D (2000) An analysis of workplace bullying in the UK. Personnel review 29(5): 593-610. 
Lewis D, Giga S and Hoel H (2011) Discrimination and bullying. In: Einarsen S, Hoel H, Zapf D and Cooper CL (eds) Bullying and Harassment in the Workplace, 2nd edn. Boca Raton, FL: Taylor \& Francis, 267-281.

Liefooghe APD and Davey KM (2001) Accounts of workplace bullying: The role of the organisation. European Journal of Work \& Organisational Psychology 10(4): 375-392.

Lim S, Cortina LM and Magley VJ (2008) Personal and workgroup incivility: Impact on work and health outcomes. Journal of Applied Psychology 93(1): 95-107.

Lutgen-Sandvik P (2006) Take this job and...: Quitting and other forms of resistance to workplace bullying. Communication Monographs 73(4): 406-433.

McAvoy BR and Murtagh J (2003) Workplace bullying: The silent epidemic. British Medical Journal 326(7393): 776-777.

McCarthy P and Mayhew C (2004) Safeguarding the Organisation against Violence and Bullying. New York: Palgrave Macmillan.

Miles MB and Huberman AM (1994) Qualitative Data Analysis: A Sourcebook of New Methods, 2nd edn. Beverley Hills, CA: SAGE.

O'Moore M, Seigne E, McGuire L and Smith M (1998) Victims of workplace bullying in Ireland. The Irish Journal of Psychology 19(2-3): 345-357.

Oskoc H, Gurler OK and Ucdogruk S (2011) Decomposition of income inequality in Turkey. Current Research Journal of Social Sciences 3(2): 96-103.

Rayner C (1997) The incidence of workplace bullying. Journal of Community \& Applied Social Psychology 7(3): 199-208.

Rayner C and Cooper CL (2006) Workplace bullying. In: Kelloway EK, Barling J and Hurrell JJ (eds) Handbook of Workplace Violence. London: SAGE, 121-147.

Rayner C, Hoel H and Cooper CL (2002) Workplace Bullying: What We Know, Who is to Blame and What Can We Do? London: Taylor \& Francis.

Reskin BF (2003) Modeling ascriptive inequality: From motives to mechanisms. American Sociological Review 68(1): 1-21.

Reskin BF and Ross CE (1992) Jobs, authority, and earnings among managers the continuing significance of sex. Work and Occupations 19(4): 342-365.

Ridgeway C (1991) The social construction of status value: Gender and other nominal characteristics. Social Forces 70(2): 367-386.

Ridgeway CL and Balkwell JW (1997) Group processes and the diffusion of status beliefs. Social Psychology Quarterly 60(1): 14-31.

Salin D (2003a) Bullying and organisational politics in competitive and rapidly changing work environments. International Journal of Management \& Decision Making 4(1): 35-46.

Salin D (2003b) Ways of explaining workplace bullying: A review of enabling, motivating and precipitating structures and processes in the work environment. Human relations 56(10): $1213-1232$.

Salter M (2010) Lawful but corrupt: Gaming and the problem of institutional corruption in the private sector. Harvard Business School Research Paper: 11-060.

Sen AK (1997) From income inequality to economic inequality. Southern Economic Journal 64(2): 384-401.

Seymour R (2013) Istanbul park protests sow the seeds of a Turkish Spring. Available at: http:// www.guardian.co.uk/commentisfree/2013/may/31/istanbul-park-protests-turkish-spring, accessed July 2013

Sheehan M, Barker M and Rayner C (1999) Applying strategies for dealing with workplace bullying. International journal of manpower 20(1/2): 50-57.

Sidanius J and Pratto F (1999) Social Dominance: An Intergroup Theory of Social Hierarchy and Oppression. Cambridge: Cambridge University Press. 
Slaughter MJ (2007) Globalization and declining unionization in the United States. Industrial Relations: A Journal of Economy and Society 46(2): 329-346.

Sorensen AB (2000) Towards a sounder basis for class analysis. American Journal of Sociology 105(6): 1523-1558.

Soylu S (2011) Creating a family or loyalty-based framework: The effects of paternalistic leadership on workplace bullying. Journal of Business Ethics 99(2): 217-231.

Tajfel H and Turner JC (1979) An integrative theory of intergroup conflict. In: Austin W and Worchel S (eds) The Social Psychology of Intergroup Relations. Pacific Grove, CA: Brooks/ Cole, 33-48.

Tilly C (1998) Durable Inequality. Berkeley, CA: University of California Press.

Toprak B, Bosan I, Morgül T and Şener N (2008) Being Different in Turkey: Alienation on the Axis of Conservatism and Religion. Istanbul: Open Society Institute Turkey.

Turkish Statistics Institute (2012) Income and Living Conditions Survey data sets 2002-2012. Available at: http://www.tuik.gov.tr, accessed November 2013.

Verkuyten M and Yildiz AA (2006) The endorsement of minority rights: The role of group position, national context, and ideological beliefs. Political Psychology 27(4): 527-548.

Weber M (1968) Economy and Society. New York: Bedminister.

Zapf D and Einarsen S (2011) Individual antecedents of bullying: Victims and perpetrators. In: Einarsen S, Hoel H, Zapf D and Cooper CL (eds) Bullying and Harassment in the Workplace. Boca Raton, FL: Taylor \& Francis, 177-201.

Soydan Soylu is a lecturer in Organizational Psychology at Middlesex University Business School, UK. He completed his MSc and PhD at the London School of Economics (LSE), Department of Social Psychology. His doctoral study focused on workplace bullying in the Turkish context. Prior to joining Middlesex University, Dr Soylu was a visiting fellow at Harvard University, Department of Psychology, and he worked at the LSE, Department of Management from 2011 to 2013 as a postdoctoral research fellow. His research interests include the dark side of behaviours at work, business ethics, paternalistic leadership, intergroup relations and the determinants of societal inequality. Dr Soylu's work has been published in Journal of Business Ethics. [Email: s.soylu@mdx.ac.uk]

Jennifer Sheehy-Skeffington is a post-doctoral fellow at the Department of Psychology, University of Oslo, Norway. She completed her PhD at Harvard University, where she was awarded a Multidisciplinary Fellowship in Inequality and Social Policy by the Harvard Kennedy School, and her MSc at the London School of Economics, where she won the Hilde T Himmelweit Prize. Jennifer's research centres on the psychology of power and status as it manifests in intergroup relations, organizational behaviour, and the dynamics of societal inequality. Jennifer has published in outlets including Behavioral and Brain Sciences, Journal of Personality and Personality and Social Psychology Bulletin, while also writing for the World Bank and United Nations Development Programme on the behavioural economics of poverty. [Email: jsheehy@fas.harvard.edu] 
